\title{
Studies of the Cyclopolymerization in the Presence of Alkylaluminum Chlorides. VI. Cyclopolymerizations of 2-(o-Allylphenoxy)ethyl Methacrylate and the Higher Homologues in the 11-19-Membered-Ring Region
}

\author{
Kazuaki YoKota, Toyoji KaKUCHI, Atsushi NANASAwA, \\ Jun-ichi IWATA, and Yoshiyuki TAKADA \\ Department of Chemical Process Engineering, Faculty of Engineering, \\ Hokkaido University, Sapporo 060, Japan.
}

(Received September 5, 1981)

\begin{abstract}
An investigation of effects of alkylaluminum chlorides on the cyclopolymerization was extended to 2-(o-allylphenoxy)ethyl, 4-(o-allylphenoxy)butyl, 6-(o-allylphenoxy)hexyl, and 10-(o-allylphenoxy)decyl methacrylates (2-AOEM, 4-AOBM, 6-AOHM, and 10-AODM) which are capable of forming 11-, 13-, 15-, and 19-membered rings, respectively. The addition of alkylaluminum chlorides to these monomers was effective for increasing the extent of cyclization. The effect of alkylaluminum chlorides was remarkable in formation of the 11-membered ring, but was suddenly less for lower membered rings. Considerable along with previous results, the present data provide insight into the difference in the reactivities between the acrylates and the methacrylates. Although the cyclopolymerization tendency was larger for the former than for the latter, the relation of $\log \left(k_{\mathrm{p}} / k_{\mathrm{c}}\right)$ against ring size gave straight lines having about the same slope in the ring-size range from 8 to 15 for both monomer series. Therefore, there is not substantial difference in a mechanism of the cyclopolymerization between the acrylates and the methacrylates.

KEY WORDS Cyclopolymerization / Alkylaluminum Chlorides / 2- $(o-$

Allylphenoxy)ethyl Methacrylate / Nonconjugated Diene / Methacrylates /

Acrylates / Radical Polymerization / Large-Size Ring / Cyclization /
\end{abstract}

In a previous paper ${ }^{1}$ the authors reported that the cyclopolymerization tendency of $o$-allylphenyl acrylate (APA) containing electro-positive and electro-negative double bonds greatly increased by alkylaluminum chlorides. Highly cyclized polymers were obtained not only from APA in the formation of 8-membered rings, but also from 2-(o-allylphenoxy)ethyl and 4-(o-allylphenoxy)butyl acrylate (2-AOEA and 4-AOBA) ${ }^{2}$ in the formation of 11and 13-membered rings, respectively. The alkylaluminum chlorides function as a complexing agent between the electron-donor and the electronacceptor groups in the molecule; the ability of complex formation decreased with increasing ring size to be formed. These agents caused a moderate increase in the cyclopolymerization tendency of 6$(o \text {-allylphenoxy)hexyl acrylate (6-AOHA })^{3}$ capable of forming 15-membered rings, but had little effect on the polymerization of 10-(o-allylphenoxy)decyl acrylate (10-AODA) ${ }^{3}$ of 19 -membered rings.

Otsu et $a l .{ }^{4}$ showed that Lewis acids, such as $\mathrm{SnCl}_{4}$ and $\mathrm{AlEt}_{1.5} \mathrm{Cl}_{1.5}$, have a marked effect on the cyclopropagation in the polymerizations of allyl acrylate and methacrylate.

The addition of alkylaluminum chlorides to $o$ allylphenyl methacrylate (APM) produced effects different from that of APA. ${ }^{5}$ The oligomers were preferentially obtained above the $\mathrm{Al} / \mathrm{M}$ molar ratio of 1.0 in the presence of $\mathrm{AlEt}_{2} \mathrm{Cl}$. Such an oligomerization was observed on the reaction of methyl methacrylate with $\mathrm{AlEt}_{2} \mathrm{Cl}$ as well, and trimers composed of the bridged bicyclic lactone were isolated. ${ }^{6,7}$

This paper reports the effect of alkylaluminum chlorides upon the methacrylates, namely, 2-(oallylphenoxy)ethyl, 4-(o-allylphenoxy)butyl, 6-(oallylphenoxy)hexyl, and 10-(o-allylphenoxy)decyl methacrylates (2-AOEM, 4-AOBM, 6-AOHM, and . 


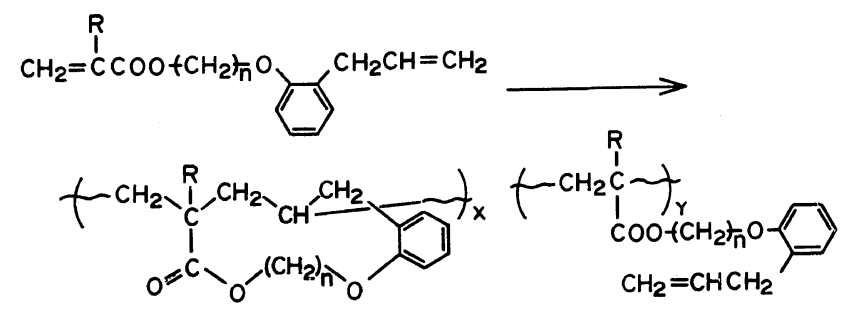

$\mathrm{R}=\mathrm{H}$ (acrylates): $n=2,2$-AOEA (ring size, 11); $n=4,4$-AOBA (13); $n=6,6$-AOHA (15); $n=10,10$ AODA (19).

$\mathrm{R}=\mathrm{CH}_{3}$ (methacrylates): $n=2,2$-AOEM (11); $n=4,4-\mathrm{AOBM}(13) ; n=6,6-\mathrm{AOHM}(15) ; n=10,10-$ AODM (19).

10-AODM), in comparison with acrylates.

A limited amount of work was carried out with the cyclopolymerizations of monomers capable of forming large-size rings. ${ }^{8-12}$ Moreover, there are very few reports ${ }^{8,9}$ on quantitative work in this field. Thus, in the present paper the influence of ring size on the cyclopolymerization tendency for the acrylates and the methacrylates is presented.

For these monomers the direction of polymerization is depicted in above eq 1 .

\section{EXPERIMENTAL}

\section{Monomers}

2-(o-Allylphenoxy)ethyl, 4-(o-allylphenoxy)butyl, 6-(o-allylphenoxy)hexyl, and 10-(o-allylphenoxy)decyl methacrylate were obtained from methacryloyl chloride and the corresponding alcohols by a procedure similar to that described in the previous papers. ${ }^{1-3}$

2-(o-Allylphenoxy)ethyl methacrylate: bp $145^{\circ} \mathrm{C}$ $(2.5 \mathrm{mmHg}) ; d_{4}^{20} 1.0430 ; \mathrm{NMR}\left(\mathrm{CCl}_{4}\right) \delta 1.95(\mathrm{~s}, 3$, $\left.-\mathrm{C}\left(\mathrm{CH}_{3}\right)=\right), 3.37\left(\mathrm{~d}, 2, J=6.5 \mathrm{~Hz},-\mathrm{C}_{2} \mathrm{CH}=\right)$, $4.20\left(\mathrm{t}, 2, J=5 \mathrm{~Hz}, \mathrm{ArOCH}_{2}-\right), 4.51(\mathrm{t}, 2, J=5 \mathrm{~Hz}$, $\left.-\mathrm{COOCH}_{2}-\right), \quad 5.00 \quad(\mathrm{~d}, \quad 1, \quad J=11.0 \mathrm{~Hz}, \quad$ cis$\left.\mathrm{CH}_{2}=\mathrm{CH}-\right), 5.02\left(\mathrm{~d}, 1, J=15.5 \mathrm{~Hz}\right.$, trans $-\mathrm{CH}_{2}=$ $\mathrm{CH}-), 5.58\left(\mathrm{~s}, 1\right.$, cis- $\left.\mathrm{CH}_{2}=\mathrm{C}\left(\mathrm{CH}_{3}\right)-\right), 5.78-6.10(\mathrm{~m}$, 1, $\left.-\mathrm{C} \underline{\mathrm{H}}=\mathrm{CH}_{2}\right), 6.14\left(\mathrm{~s}, 1\right.$, trans- $\left.\mathrm{CH}_{2}=\mathrm{C}\left(\mathrm{CH}_{3}\right)-\right)$, $6.90(\mathrm{t}, 2, J=7 \mathrm{~Hz}, 4-$ and 5-ArH), $7.14 \mathrm{ppm}(\mathrm{d}, 2$, $J=7.5 \mathrm{~Hz}, 3-$ and $6-\mathrm{ArH}$ ).

Anal. Calcd for $\mathrm{C}_{15} \mathrm{H}_{18} \mathrm{O}_{3}: \mathrm{C}, 73.14 \%$; $\mathrm{H}, 7.37 \%$. Found: C, $73.27 \% ; \mathrm{H}, 7.28 \%$.

4-(o-Allylphenoxy)butyl methacrylate: bp $157^{\circ} \mathrm{C}$ $(2 \mathrm{mmHg}) ; d_{4}^{20} 1.0230 ; \mathrm{NMR}\left(\mathrm{CCl}_{4}\right) \delta 1.93$ (narrow $\mathrm{m}, 7, \mathrm{C}\left(\mathrm{CH}_{3}\right)=$ and $\left.-\mathrm{OCH}_{2} \mathrm{CH}_{2}-\right), 3.37(\mathrm{~d}, 2, J=$ $\left.6.5 \mathrm{~Hz},-\mathrm{CH}_{2} \mathrm{CH}=\right), 4.01\left(\mathrm{~m}, 2, \mathrm{ArOCH}_{2}-\right), 4.22$ $\left(\mathrm{m}, 2,-\mathrm{COOCH}_{2}-\right), 5.01\left(\mathrm{~d}, 2, J=12.0 \mathrm{~Hz}, \mathrm{C}_{2}=\right.$
$\mathrm{CH}-$ ), 5.53 (s, 1, cis- $\left.\mathrm{C}_{2}=\mathrm{C}\left(\mathrm{CH}_{3}\right)-\right), 5.75-6.10$ (m, 1, $\left.-\mathrm{C} \underline{\mathrm{H}}=\mathrm{CH}_{2}\right), \quad 6.09 \quad\left(\mathrm{~s}, \quad 1\right.$, trans $-\mathrm{CH}_{2}=$ $\left.\mathrm{C}\left(\mathrm{CH}_{3}\right)-\right), 6.83$ (t, $2, J=7.5 \mathrm{~Hz}$, 4- and 5-ArH), 7.11 ppm (d, 2, $J=7.0 \mathrm{~Hz}, 3-$ and 6-ArH).

Anal. Calcd for $\mathrm{C}_{17} \mathrm{H}_{22} \mathrm{O}_{3}: \mathrm{C}, 74.42 \% ; \mathrm{H}, 8.08 \%$. Found: C, $74.34 \% ; \mathrm{H}, 8.11 \%$.

6-(o-Allylphenoxy)hexyl methacrylate: bp $178^{\circ} \mathrm{C}(2 \mathrm{mmHg}) ; d_{4}^{20} 1.0030 ; \mathrm{NMR}\left(\mathrm{CCl}_{4}\right) \delta 1.50-$ $1.90\left(\mathrm{~m}, 8,-\mathrm{CH}_{2}-\right), 1.96\left(\mathrm{~s}, 3,-\mathrm{C}\left(\mathrm{CH}_{3}\right)=\right), 3.39(\mathrm{~d}, 2$, $\left.J=6.0 \mathrm{~Hz}, \quad-\mathrm{CH}_{2} \mathrm{CH}=\right), \quad 3.39 \quad(\mathrm{t}, \quad 2, \quad J=6 \mathrm{~Hz}$, $\left.\mathrm{ArOCH}_{2}-\right), 4.17\left(\mathrm{t}, 2, J=6.0 \mathrm{~Hz},-\mathrm{COOCH}_{2}-\right), 5.04$ (d, 2, J=13 Hz, cis- $\mathrm{CH}_{2}=\mathrm{CH}-$ ), 5.05 (d, 2, $J=$ $14.5 \mathrm{~Hz}$, trans $\left.-\mathrm{C}_{2}=\mathrm{CH}-\right), 5.53$ (s, 1, cis $-\underline{\mathrm{CH}}_{2}=$ $\left.\mathrm{C}\left(\mathrm{CH}_{3}\right)-\right), 5.78-6.10\left(\mathrm{~m}, 1,-\mathrm{CH}=\mathrm{CH}_{2}\right), 6.10(\mathrm{~s}, 1$, trans $\left.-\mathrm{C}_{2}=\mathrm{C}\left(\mathrm{CH}_{3}\right)-\right), 6.82(\mathrm{t}, 2, J=8.0 \mathrm{~Hz}, 4$ - and 5-ArH), $7.11 \mathrm{ppm}(\mathrm{d}, 2, J=7.5 \mathrm{~Hz}, 3-$ and $6-\mathrm{ArH})$. Anal. Calcd for $\mathrm{C}_{19} \mathrm{H}_{26} \mathrm{O}_{3}: \mathrm{C}, 75.46 \% ; \mathrm{H}, 8.67 \%$. Found: $\mathrm{C}, 75.42 \% ; \mathrm{H}, 8.71 \%$.

10-(o-Allylphenoxy)decyl methacrylate: a pale yellow oil obtained by distillation, using a glass tube oven (Büchi Ltd., Model GKR-50); $d_{4}^{20} 0.9701$; $\operatorname{NMR}\left(\mathrm{CCl}_{4}\right) \delta 1.34$ (narrow $\mathrm{m}, 16,-\mathrm{CH}_{2}-$ ), 1.91 (s, $\left.3,-\mathrm{C}\left(\mathrm{CH}_{3}\right)=\right), 3.32\left(\mathrm{~d}, 2, J=6.5 \mathrm{~Hz},-\mathrm{C}_{2} \mathrm{CH}=\right)$, $3.93\left(\mathrm{t}, 2, J=6 \mathrm{~Hz}, \mathrm{ArOCH}_{2}-\right), 4.09(\mathrm{t}, 2, J=6.5 \mathrm{~Hz}$, $\left.-\mathrm{COOCH}_{2}-\right), 4.97$ (d, $1, J=11.5 \mathrm{~Hz}$, cis $-\mathrm{CH}_{2}=$ $\mathrm{CH}-$ ), $5.06\left(\mathrm{~d}, 1, J=15.5 \mathrm{~Hz}\right.$, trans $-\mathrm{CH}_{2}=\mathrm{CH}-$ ), 5.49 (s, 1 , cis- $\left.\mathrm{C}_{2}=\mathrm{C}\left(\mathrm{CH}_{3}\right)-\right), 5.72-6.05(\mathrm{~m}, 1$, $\left.-\mathrm{C} \underline{\mathrm{H}}=\mathrm{CH}_{2}\right), 6.09\left(\mathrm{~s}, 1\right.$, trans $\left.-\mathrm{C}_{2}=\mathrm{C}\left(\mathrm{CH}_{3}\right)-\right), 6.80$ (t, $2, J=7.0 \mathrm{~Hz}, 4$ - and 5-ArH), $7.06 \mathrm{ppm}$ (d, 2, $J=$ $8.0 \mathrm{~Hz}, 3-$ and 6-ArH).

Anal. Calcd for $\mathrm{C}_{23} \mathrm{H}_{34} \mathrm{O}_{3}$ : C, $77.05 \%$; $\mathrm{H}, 9.56 \%$. Found: C, $77.13 \%$; H, $9.78 \%$.

\section{Polymerization}

The polymerizations were carried out as described in a previous paper. ${ }^{1}$ 
Analysis

The extent of cyclization in polymers was determined by the procedure described in our previous papers. ${ }^{1-3}$ The molecular weights of the polymer samples were measured in benzene at $40^{\circ} \mathrm{C}$, using a vapor pressure osmometer (Hitachi Ltd., Model 117).

\section{RESULTS}

Polymerization of 2-(o-Allylphenoxy)ethyl Methacrylate (2-AOEM)

Experimental results of the conventional radical polymerization without alkylaluminum chlorides are presented in Table I. The products obtained at a higher monomer concentration were somewhat sticky semi-solids, while colorless amorphous powders were obtained at lower concentration. The IR spectra of the polymers are indicative of a large amount of residual double bonds in the form of pendant allylic double bonds, as shown by the absence of the characteristic absorption of methacylic double bonds at $810 \mathrm{~cm}^{-1}$. The extent of cyclization was $37 \%$ at a monomer concentration of 0.5 $\mathrm{mol} \mathrm{dm}{ }^{-3}$.

For the polymerization in the presence of $\mathrm{AlEt}_{2} \mathrm{Cl}$ and $\mathrm{AlEt}_{1.5} \mathrm{Cl}_{1.5}$, the reaction system was homogeneous, but a somewhat sticky precipitate separated above the $\mathrm{Al} / \mathrm{M}$ molar ratio of 1.0 in the presence of $\mathrm{AlEtCl}_{2}$. The polymers were colorless powders soluble in chloroform. A portion of the polymers obtained at the $\mathrm{Al} / \mathrm{M}$ ratio in the range

Table I. Radical polymerization of 2-(o-allylphenoxy)ethyl methacrylate ${ }^{a}$

\begin{tabular}{|c|c|c|c|}
\hline$[\mathrm{M}]$ & Time & Conversion & $\begin{array}{l}\text { Extent of } \\
\text { cyclization }\end{array}$ \\
\hline $\mathrm{mol} \mathrm{dm}^{-3}$ & $\mathrm{~h}$ & $\%$ & $\%$ \\
\hline 4.61 & 0.3 & 14.1 & 11.0 \\
\hline 3.04 & 1.0 & 36.2 & 14.0 \\
\hline 2.51 & 1.5 & 44.1 & 11.0 \\
\hline 1.99 & 2.0 & 34.8 & 10.0 \\
\hline 1.50 & 2.5 & 44.8 & 19.0 \\
\hline 1.00 & 3.0 & 35.3 & 22.0 \\
\hline 0.50 & 6.1 & 27.6 & 37.0 \\
\hline
\end{tabular}

a Solvent, toluene; $\mathrm{AIBN} / \mathrm{M}$ molar ratio, 0.045; temp, $60^{\circ} \mathrm{C}$.
$1.0-1.5$ were insoluble in organic solvents. The polymerization was not accompanied by oligomerization in contrast to the state of APM. ${ }^{5}$ The residual double bonds in the polymer consisted of allylic bonds. The effect of alkylaluminum chlorides is shown in Table II. A comparison with the corresponding acrylate, $2-\mathrm{AOEA},{ }^{2}$ is presented in Figure 1. The rate of polymerization is indicated by a conversion within $4 \mathrm{hr}$ for 2-AOEM and $20 \mathrm{~min}$ for 2-AOEA. Each of the alkylaluminum chlorides was effective for increasing the rate of polymer-

Table II. Polymerization of 2-(oallylphenoxy)ethyl methacrylate in the presence of alkylaluminum chlorides $^{\mathrm{a}}$

\begin{tabular}{|c|c|c|c|c|}
\hline $\mathrm{Al} / \mathrm{M}$ & Time & Conversion & $\begin{array}{l}\text { Extent of } \\
\text { cylization }\end{array}$ & $\begin{array}{l}\text { Molecular } \\
\text { weight of }\end{array}$ \\
\hline Molar ratio & $\mathrm{h}$ & $\%$ & $\%$ & polymer \\
\hline
\end{tabular}

\begin{tabular}{|c|c|c|c|c|}
\hline \multicolumn{5}{|l|}{$\mathrm{AlEt}_{2} \mathrm{Cl}$} \\
\hline 0.25 & 6 & 12.2 & 44.5 & 5000 \\
\hline 0.5 & & 21.0 & 40.5 & 2800 \\
\hline 0.75 & & 26.6 & 47.0 & 2700 \\
\hline 1.0 & & 28.8 & 45.0 & 2800 \\
\hline 1.25 & & 27.0 & 47.0 & 2900 \\
\hline 1.5 & & 34.3 & 50.5 & - \\
\hline 1.75 & & 28.8 & 62.2 & 3800 \\
\hline 2.0 & & 28.9 & 74.0 & 3900 \\
\hline \multicolumn{5}{|c|}{$\mathrm{AlEt}_{1.5} \mathrm{Cl}_{1.5}$} \\
\hline 0.25 & 4 & 12.5 & 43.5 & - \\
\hline 0.5 & & 15.8 & 55.5 & 11300 \\
\hline 0.75 & & 20.5 & 58.0 & 12400 \\
\hline 1.0 & & 25.0 & 62.0 & 12000 \\
\hline 1.25 & & 29.5 & 72.0 & - \\
\hline 1.5 & & 33.1 & 71.5 & 7000 \\
\hline 1.75 & & 35.7 & 76.5 & 9000 \\
\hline 2.0 & & 39.7 & 82.5 & 7800 \\
\hline \multicolumn{5}{|l|}{$\mathrm{AlEtCl}_{2}$} \\
\hline 0.25 & 4 & 11.7 & 55.5 & 26000 \\
\hline 0.5 & & 18.1 & 59.5 & 13600 \\
\hline 0.75 & & 10.4 & 57.5 & 12500 \\
\hline 1.0 & & 36.1 & 75.5 & $-^{\mathrm{b}}$ \\
\hline 1.25 & & 45.5 & 87.0 & $-^{\mathrm{b}}$ \\
\hline 1.5 & & 41.6 & 84.0 & $-^{\mathrm{b}}$ \\
\hline 1.75 & & 38.2 & 89.5 & 5800 \\
\hline 2.0 & & 30.8 & 89.5 & 5900 \\
\hline
\end{tabular}



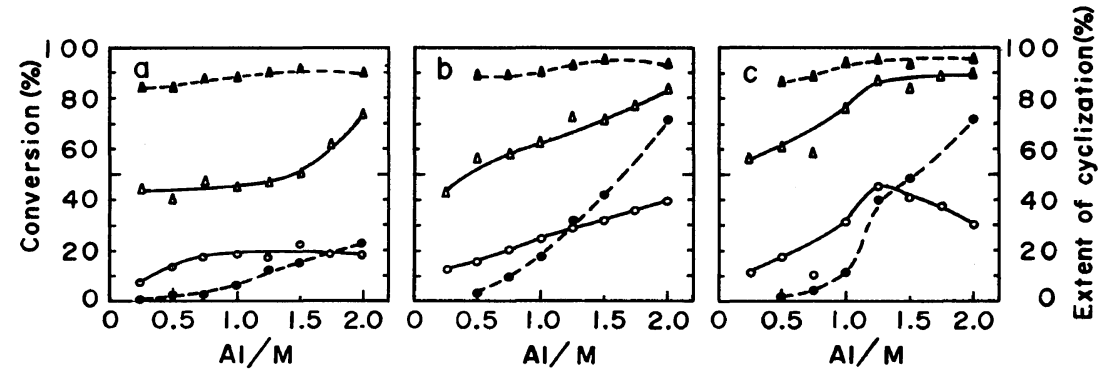

Figure 1. Effect of the $\mathrm{Al} / \mathrm{M}$ molar ratio on the polymerizations of 2-(o-allylphenoxy)ethyl acrylate and methacrylate in the presence of (a) $\mathrm{AlEt}_{2} \mathrm{Cl}$, (b) $\mathrm{AlEt}_{1.5} \mathrm{Cl}_{1.5}$, and (c) $\mathrm{AlEtCl}_{2}$ : the conversion within $20 \mathrm{~min}$ for the acrylate $(O)$ and $4 \mathrm{~h}$ for the methacrylate $(O)$; the extent of cyclization for the acrylate $(\boldsymbol{\Delta})$ and the methacrylate $(\triangle) ;[\mathrm{M}], 0.5 \mathrm{~mol} \mathrm{dm}{ }^{-3} ;$ AIBN/M molar ratio, $0.01 ;$ temp, $40^{\circ} \mathrm{C}$.

ization, but there was the different behavior of the rate regarding change in the $\mathrm{Al} / \mathrm{M}$ ratio. The extent of cyclization increased by increasing the $\mathrm{Al} / \mathrm{M}$ ratio, attaining a maximum at the ratio of 2.0: $74 \%$ for $\mathrm{AlEt}_{2} \mathrm{Cl} ; 82.5 \%$ for $\mathrm{AlEt}_{1.5} \mathrm{Cl}_{1.5} ; 89.5 \%$ for $\mathrm{AlEtCl}_{2}$. The rate of polymerization and the extent of cyclization were smaller for the methacrylate than for the acrylate, except the case in which the addition of $\mathrm{AlEtCl}_{2}$ above the $\mathrm{Al} / \mathrm{M}$ ratio of 1.0 gave a cyclization extent comparable to that for the acrylate.

Polymerization of 4-(o-Allylphenoxy)butyl Methacrylate (4- $A O B M$ )

Experimental results of the polymerization without alkylaluminum chlorides are presented in Table III. The products obtained were somewhat sticky semi-solids. The polymers contained a large amount of residual double bonds consisting of allylic bonds. The extent of cyclization was $20 \%$ at a monomer concentration of $0.5 \mathrm{~mol} \mathrm{dm}^{-3}$.

Table III. Radical polymerization of 4-(o-allylphenoxy)butyl methacrylate $^{\mathrm{a}}$

\begin{tabular}{|c|c|c|c|}
\hline$[\mathrm{M}]$ & Time & Conversion & $\begin{array}{l}\text { Extent of } \\
\text { cylization }\end{array}$ \\
\hline $\mathrm{mol} \mathrm{dm}^{-3}$ & $\mathrm{~h}$ & $\%$ & $\%$ \\
\hline 2.93 & 0.5 & 12.0 & 9.5 \\
\hline 1.98 & 1.0 & 26.3 & 13.0 \\
\hline 1.02 & 2.0 & 35.2 & 17.0 \\
\hline 0.50 & 3.0 & 22.5 & 20.0 \\
\hline
\end{tabular}

a Solvent, toluene; AIBN/M molar ratio, 0.045; temp, $60^{\circ} \mathrm{C}$.
Table IV. Polymerization of 4-(oallylphenoxy)butyl methacrylate in the presence of alkylaluminum chlorides $^{\mathrm{a}}$

\begin{tabular}{|c|c|c|c|c|}
\hline $\mathrm{Al} / \mathrm{M}$ & Time & Conversion & $\begin{array}{l}\text { Extent of } \\
\text { cyclization }\end{array}$ & Molecular \\
\hline Molar ratio & $\mathrm{h}$ & $\%$ & $\%$ & polymer \\
\hline \multicolumn{5}{|l|}{$\mathrm{AlEt}_{2} \mathrm{Cl}$} \\
\hline 0.25 & 9 & 19.3 & 15.0 & - \\
\hline 0.5 & & 29.6 & 14.0 & - \\
\hline 0.75 & & 27.7 & 14.0 & - \\
\hline 1.0 & & 21.8 & 22.0 & 3500 \\
\hline 1.25 & & 19.6 & 31.0 & 3500 \\
\hline 1.5 & & 19.2 & 32.0 & 3700 \\
\hline 1.75 & & 15.3 & 29.5 & 3400 \\
\hline 2.0 & & 12.7 & 29.0 & 3100 \\
\hline \multicolumn{5}{|l|}{$\mathrm{AlEt}_{1.5} \mathrm{Cl}_{1.5}$} \\
\hline 0.25 & 4 & 7.3 & 15.5 & - \\
\hline 0.5 & & 10.0 & 12.5 & - \\
\hline 0.75 & & 10.8 & 20.0 & - \\
\hline 1.0 & & 13.5 & 21.0 & 10300 \\
\hline 1.25 & & 14.4 & 21.5 & 12800 \\
\hline 1.5 & & 14.7 & 28.0 & 10600 \\
\hline 1.75 & & 19.5 & 32.5 & 6700 \\
\hline 2.0 & & 25.9 & 41.0 & 8800 \\
\hline \multicolumn{5}{|l|}{$\mathrm{AlEtCl}{ }_{2}$} \\
\hline 0.25 & 4 & 5.7 & 15.5 & - \\
\hline 0.5 & & 10.5 & 12.5 & - \\
\hline 0.75 & & 11.5 & 24.0 & 9200 \\
\hline 1.0 & & 14.8 & 37.0 & 7800 \\
\hline 1.25 & & 26.9 & 39.5 & 8200 \\
\hline 1.5 & & 25.3 & 39.5 & 7800 \\
\hline 1.75 & & 23.6 & 31.5 & 6100 \\
\hline 2.0 & & 15.1 & 24.5 & 5200 \\
\hline
\end{tabular}

a Solvent, toluene; [M], $0.5 \mathrm{~mol} \mathrm{dm}^{-3} ; \mathrm{AIBN} / \mathrm{M}$ molar ratio, 0.015 ; temp, $40^{\circ} \mathrm{C}$.

Polymer J., Vol. 14, No. 7, 1982 

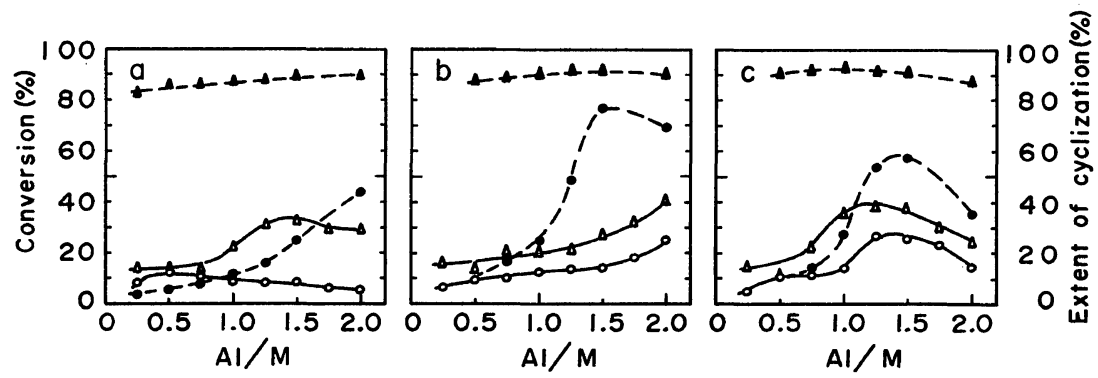

Figure 2. Effect of the $\mathrm{Al} / \mathrm{M}$ molar ratio on the polymerizations of 4-(o-allylphenoxy)butyl acrylate and methacrylate in the presence of (a) $\mathrm{AlEt}_{2} \mathrm{Cl}$, (b) $\mathrm{AlEt}_{1.5} \mathrm{Cl}_{1.5}$, and (c) $\mathrm{AlEtCl}_{2}$ : the conversion within $2 \mathrm{~h}$ for the acrylate $(\bigcirc)$ and $4 \mathrm{~h}$ for the methacrylate $(\bigcirc)$; the extent of cyclization for the acrylate $(\boldsymbol{\Delta})$ and the methacrylate $(\triangle) ;[\mathrm{M}], 0.5 \mathrm{~mol} \mathrm{dm}^{-3} ;$ AIBN/M molar ratio, $0.01 ;$ temp, $40^{\circ} \mathrm{C}$.

The behavior of polymerization in the presence of the alkylaluminum chlorides was similar to that of 2-AOEM. The polymer obtained in the presence of $\mathrm{AlEt}_{2} \mathrm{Cl}$ was soluble even when the conversion reached $60 \%$. Gelation occurred at a conversion above $50 \%$ in the presence of $\mathrm{AlEt}_{1.5} \mathrm{Cl}_{1.5}$ and $\mathrm{AlEtCl}_{2}$. The effect of the alkylaluminum chlorides is shown in Table IV. A comparison with the acrylate, $4-\mathrm{AOBA},{ }^{2}$ is presented in Figure 2 . The rate of polymerization is indicated by the conversion within $4 \mathrm{~h}$ for 4 -AOBM and $2 \mathrm{~h}$ for 4 AOBA. The alkylaluminum chlorides brought about an increase in the rate of polymerization and the extent of cyclization, but there was a subtle difference in rates and cyclization extents among the alkylaluminum chlorides. The extent of cyclization attained a maximum at a ratio of 2.0 or below: $32 \%$ for $\mathrm{AlEt}_{2} \mathrm{Cl} ; 41 \%$ for $\mathrm{AlEt}_{1.5} \mathrm{Cl}_{1.5} ; 39.5 \%$ for $\mathrm{AlEtCl}_{2}$.

A two-member increase in the ring to be formed caused a considerable decrease in the extent of cyclization; this is in striking contrast to the acrylate which continued to maintain high extent of cyclization in the formation of 13-membered rings.

\section{Polymerizations of 6-(o-Allylphenoxy)hexyl and 10- (o-Allylphenoxy)decyl Methacrylate (6-AOHM and 10-AODM)}

Polymerization without alkylaluminum chlorides caused the extent of cyclization to drop from 9 to $2 \%$ for 6 -AOHM and from 10.5 to $4.5 \%$ for 10 AODM at monomer concentrations ranging from 0.5 to $2.0 \mathrm{~mol} \mathrm{dm}^{-3}$ at $60^{\circ} \mathrm{C}$.

For polymerization in the presence of alkylaluminum chlorides, the reaction system was homogeneous and the polymer obtained was soluble in chloroform. The results are shown in Figures 3 and 4. The rate of polymerization is indicated by conversion within $10 \mathrm{~h}$ for 6-AOHM and $2 \mathrm{~h}$ for 6 AOHA in Figure 3, and within $10 \mathrm{~h}$ for 10-AODM
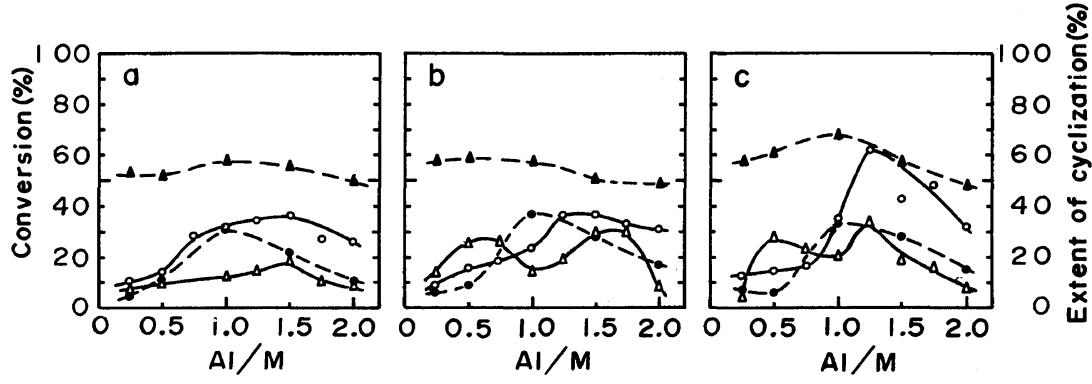

Figure 3. Effect of the $\mathrm{Al} / \mathrm{M}$ molar ratio on the polymerizations of 6-(o-allylphenoxy)hexyl acrylate and methacrylate in the presence of (a) $\mathrm{AlEt}_{2} \mathrm{Cl}$, (b) $\mathrm{AlEt}_{1.5} \mathrm{Cl}_{1.5}$, and (c) $\mathrm{AlEtCl}_{2}$ : the conversion within $2 \mathrm{~h}$ for the acrylate $(O)$ and $10 \mathrm{~h}$ for the mechacrylate $(O)$; the extent of cyclization for the acrylate $(\boldsymbol{A})$ and the methacrylate $(\triangle) ;[\mathrm{M}], 0.5 \mathrm{~mol} \mathrm{dm}^{-3} ; \mathrm{AIBN} / \mathrm{M}$ molar ratio, $0.01 ;$ temp, $40^{\circ} \mathrm{C}$. 


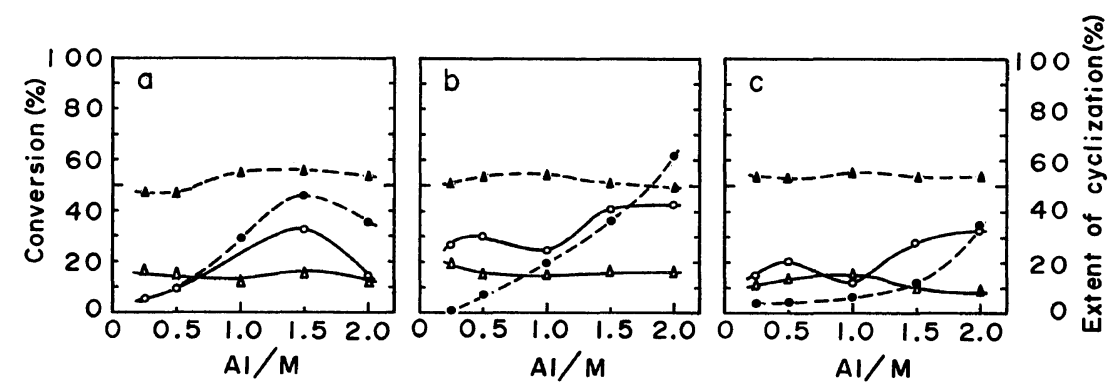

Figure 4. Effect of the $\mathrm{Al} / \mathrm{M}$ molar ratio on the polymerizations of 10-(o-allylphenoxy)decyl acrylate and methacrylate in the presence of (a) $\mathrm{AlEt}_{2} \mathrm{Cl}$, (b) $\mathrm{AlEt}_{1.5} \mathrm{Cl}_{1.5}$, and (c) $\mathrm{AlEtCl}_{2}$ : the conversion within $5 \mathrm{~h}$ for the acrylate $(\mathbf{O})$ and $10 \mathrm{~h}$ for the methacrylate $(\mathrm{O})$; the extent of cyclization for the acrylate $(\boldsymbol{\Delta})$ and the methacrylate $(\triangle) ;[\mathrm{M}], 0.5 \mathrm{~mol} \mathrm{dm}^{-3} ; \mathrm{AIBN} / \mathrm{M}$ molar ratio, $0.01 ;$ temp, $40^{\circ} \mathrm{C}$.

and $5 \mathrm{~h}$ for 10-AODA in Figure 4. The addition of alkylaluminum chlorides to 6-AOHM slightly increased the rate of polymerization and the extent of cyclization with a considerable change in the $\mathrm{Al} / \mathrm{M}$ ratio. The maximum value in the extent of cyclization was $18 \%$ for $\mathrm{AlEt}_{2} \mathrm{Cl}, 31 \%$ for $\mathrm{AlEt}_{1.5} \mathrm{Cl}_{1.5}$, and $34 \%$ for $\mathrm{AlEtCl}_{2}$. The polymerization of 10 AODM showed a lesser increase in the rate of polymerization and the extent of cyclization. The extent of cyclization was $17 \%$ for $\mathrm{AlEt}_{2} \mathrm{Cl}, 20 \%$ for $\mathrm{AlEt}_{1.5} \mathrm{Cl}_{1.5}$, and $15 \%$ for $\mathrm{AlEtCl} \mathrm{C}_{2}$. Additional increase in the ring size brought about a decrease in the extent of cyclization to a level close to that of conventional radical polymerization.

\section{DISCUSSION}

In the cyclopolymerizations of 2-AOEM, 4AOBM, 6-AOHM, and 10-AODM leading to the formation of 11-, 13-, 15, and 19-membered rings, the extent of cyclization and the rate of polymerization depended upon ring size, the type of alkylaluminum chloride, and the $\mathrm{Al} / \mathrm{M}$ molar ratio. In order to clarify the influence of ring size on the cyclopolymerization tendency of the acrylates and the methacrylates, a plot of cyclization extent against ring size is shown in Figures 5 and 6 along with data reported previously. ${ }^{1-3,5}$ The extent of cyclization gave a maximum value obtained under the following conditions: a monomer concentration of $0.5 \mathrm{~mol}$ $\mathrm{dm}^{-3}$, a temperature of $40^{\circ} \mathrm{C}$, and various $\mathrm{Al} / \mathrm{M}$ ratios. Polymerization without alkylaluminum chlorides gave a greater extent of cyclization for acrylates than for methacrylates. The extent of cyclization was substantially insensitive to ring size

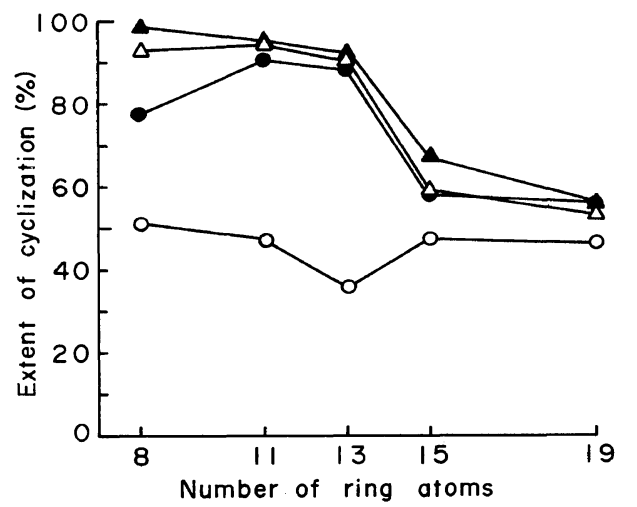

Figure 5. Extent of cyclization in the polymerizations of acrylates: without alkylaluminum chlorides $(O)$; in the presence of $\mathrm{AlEt}_{2} \mathrm{Cl}(\mathrm{O})$; in the presence of $\mathrm{AlEt}_{1.5} \mathrm{Cl}_{1.5}(\triangle)$; in the presence of $\mathrm{AlEtCl}_{2}(\mathbf{\Delta}) ;[\mathrm{M}], 0.5$ mol dm${ }^{-3}$; temp, 60 and $40^{\circ} \mathrm{C}$ without and with alkylaluminum chlorides, respectively.

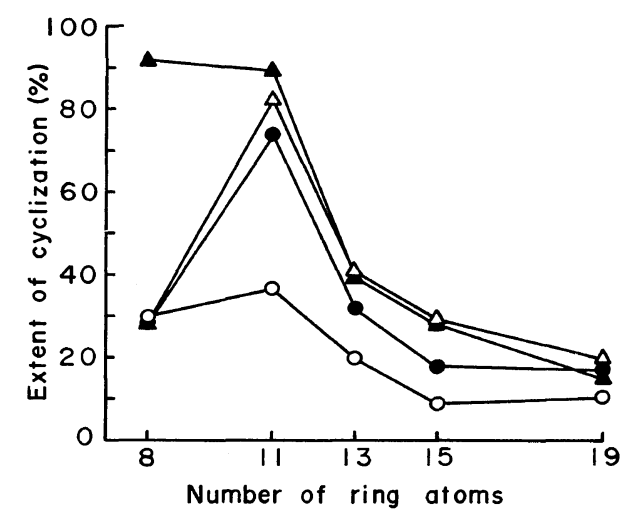

Figure 6. Extent of cyclization in the polymerizations of methacrylates: without alkylaluminum chlorides $(O)$; in the presence of $\mathrm{AlEt}_{2} \mathrm{Cl}(\mathrm{O})$; in the presence of $\mathrm{AlEt}_{1.5} \mathrm{Cl}_{1.5}(\triangle)$; in the presence of $\mathrm{AlEtCl}_{2}(\mathbf{\Delta}) ;[\mathrm{M}]$, $0.5 \mathrm{~mol} \mathrm{dm}{ }^{-3}$; temp, 60 and $40^{\circ} \mathrm{C}$ without and with alkylaluminum chlorides, respectively. 
in the former, but considerably so in the latter.

The addition of alkylaluminum chlorides increased the extent of cyclization of each monomer. For the acrylates, the extent of cyclization in the formation of 8-,11-, and 13-membered rings exceeded $90 \%$, while in the 15 - and 19 -membered ring formations a moderate increase was observed compared to conventional radical polymerization. For the methacrylates the effect of alkylaluminum chlorides was remarkable in the 8- and 11-membered rings, but was suddenly less above 11 -membered rings. The alkylaluminum chlorides induced an intramolecular interaction between the two double bonds in the same molecule to enhance the cyclopolymerization tendency of the acrylates and the methacrylates. This effect, however, was reduced with increasing ring size.

The effect of alkylaluminum chlorides on the cyclopolymerization tendency increased in the order of $\mathrm{AlEt}_{2} \mathrm{Cl}<\mathrm{AlEt}_{1.5} \mathrm{Cl}_{1.5} \leq \mathrm{AlEtCl}_{2}$, i.e., the increasing acidity of Lewis acids, with the exception of 19-membered rings. There is a considerable difference in the formation of 8-membered rings, particularly so in the case of methacrylates. The $\mathrm{AlEt}_{2} \mathrm{Cl}$ and $\mathrm{AlEt}_{1.5} \mathrm{Cl}_{1.5}$ had no effect on the extent of cyclization, but the $\mathrm{AlEtCl}_{2}$ produced a marked effect.

In regarded to the ring-closure reaction, ${ }^{13-15}$ the reactivity can be discussed in terms of strain $\left(\Delta H^{\ddagger}\right)$ and probability $\left(\Delta S^{\ddagger}\right)$. The strain energy is strongly dependent on the ring size to be formed. The formation of an 8-membered ring, which generally appears to be the most strained term in the mediumring region, particularly produces an unfavorable strain due to a superposition of the general mediumring effect onto the conformational cis effect of ester group on the lactonization. ${ }^{13-15}$ This unfavorable strain was found in the cyclopolymerization of APA and APM in the formation of 8-membered rings. When there occurred an intramolecular interaction in the polymerization process, the alkylaluminum chlorides brough about different effects for the intramolecular interaction, showing the acid strength of Lewis acids. Because of a general decrease in strain with increasing ring size, there was only a slight difference in these effects for the formation of 11- and 13-membered rings. Since an increase in ring size lowered the probability of ring closure, the alkylaluminum chlorides failed to bring about such effects on the cyclopolymerization tendency.

In order to make a quantitative comparison of the cyclopolymerization tendency, the value of $K_{\mathrm{p}} / k_{\mathrm{c}}$, the ratio of rate constants for linear propagation and cyclization, was estimated by eq $2 .{ }^{16}$

$$
\frac{1}{f_{\mathrm{c}}}=1+\frac{k_{\mathrm{p}}}{k_{\mathrm{c}}}[\mathrm{M}]
$$

For polymerization without alkylaluminum chlorides, the dependence of the extent of cyclization on the monomer concentration diminished with increasing ring size, and deviation from the intercept of 1.0 was found to increase when plotted by eq 2. For polymerization in the presence of $\mathrm{AlEt}_{2} \mathrm{Cl}$ and $\mathrm{AlEt}_{1.5} \mathrm{Cl}_{1.5}$, the intercept slightly deviated from 1.0. In the presence of $\mathrm{AlEtCl}_{2}$ the experimental data satisfied eq 2 except for the 19-membered rings. The results are summarized in Table $\mathrm{V}$ along with the available data on other monomers. ${ }^{2,3,5,17}$ The plots of $\log \left(k_{\mathrm{p}} / k_{\mathrm{c}}\right)$ against ring size are shown in Figure 7. The rate constant was greater for cyclization than linear propagation up to a 15membered ring for the acrylates and an 11-membered ring for the methacrylates. Both of these plots

Table V. The values of $k_{\mathrm{p}} / k_{\mathrm{c}}$ for the cyclopolymerizations of acrylates and methacrylates in the presence of $\mathrm{AlEtCl}_{2}{ }^{\mathrm{a}}$

\begin{tabular}{|c|c|c|c|c|c|}
\hline \multirow{2}{*}{ Acrylates } & Temp & $k_{\mathrm{p}} / k_{\mathrm{c}}$ & \multirow{2}{*}{ Methacrylates } & \multirow{2}{*}{$\frac{\text { Temp }}{{ }^{\circ} \mathrm{C}}$} & \multirow{2}{*}{$\frac{k_{\mathrm{p}} / k_{\mathrm{c}}}{\mathrm{dm}^{3} \mathrm{~mol}^{-1}}$} \\
\hline & ${ }^{\circ} \mathrm{C}$ & $\mathrm{dm}^{3} \mathrm{~mol}^{-1}$ & & & \\
\hline APA & 40 & 0.0045 & APM & 40 & 0.21 \\
\hline 11-AOEA & 20 & 0.17 & 11-AOEM & 40 & 0.56 \\
\hline 13-AOBA & 20 & 0.27 & 13-АOBM & 20 & 4.8 \\
\hline 15-AOHA & 40 & 0.99 & 15-АOHM & 20 & 7.4 \\
\hline
\end{tabular}

a $\mathrm{Al} / \mathrm{M}$ molar ratio, 1.0 . 


\section{K. Yокота et al.}

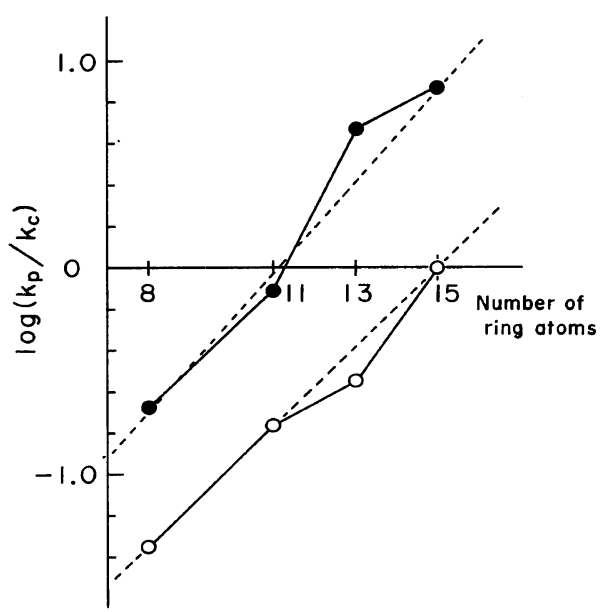

Figure 7. Variation in the values of $k_{\mathrm{p}} / k_{\mathrm{c}}$ according to ring size: for the acrylates $(O)$; for the methacrylates (O)

showed the linearity indicated by the broken lines.

According to the equation given by $\log \left(k_{\mathrm{p}} / k_{\mathrm{c}}\right)=$ $\left(\Delta G_{\mathrm{c}}{ }^{\ddagger}-\Delta G_{\mathrm{p}}{ }^{\ddagger}\right) / \mathrm{RT}$, the difference in the free energy of activation against a one-membered increase of ring size $\left(\Delta\left(\Delta G_{\mathrm{c}}{ }^{\ddagger}-\Delta G_{\mathrm{p}}{ }^{\ddagger}\right)\right)$ amounted to about 0.50 $\left(\mathrm{kJ} \mathrm{mol}^{-1}\right) / \mathrm{CH}_{2}$ for the acrylates and $0.59\left(\mathrm{~kJ} \mathrm{~mol}^{-1}\right) /$ $\mathrm{CH}_{2}$ for the methacrylates at $40^{\circ} \mathrm{C}$, where $\Delta G_{\mathrm{p}}{ }^{*}$ and $\Delta G_{\mathrm{c}}{ }^{\neq}$are the free energies of activation for the linear propagation and cyclization. Since the dependence of $\Delta H^{\neq}$and $\Delta S^{\neq}$values upon ring size is different in the small-, common-ring size regions, and beyond, ${ }^{13}$ the releation of $\log \left(k_{\mathrm{p}} / k_{\mathrm{c}}\right)$ against ring size should not be universal over a wide ringsize range. However, it was observed that a linear free energy relationship held in the ring-size range from 8 to 15 . The acrylates and the methacrylates were nearly equal in their $\Delta\left(\Delta G_{\mathrm{c}}{ }^{\ddagger}-\Delta G_{\mathrm{p}}{ }^{\ddagger}\right)$ values, indicating that it makes little difference in the influence of ring size on the effect of alkylaluminum chlorides between both monomer series. Therefore, it is found that there is not substantial difference in a mechanism of cyclization via an intramolecular interaction between the acrylates and the methacrylates.

In polymerizations with or without the alkylaluminum chlorides, the cyclopolymerization tendency of the metacrylates was less than that of the acrylates. The reason for this is the participation on the part of the methyl group in the methacrylates to exert an adverse influence on the steric and electrostatic components of the intramolecular cyclization reaction.

Acknowledgement. The authors gratefully acknolwedge support for this research provided through a grant from the Asahi Glass Foundation for Industrial Technology.

\section{REFERENCES}

1. K. Yokota, N. Hirayama, and Y. Takada, Polym. J., 7, 729, (1975).

2. K. Yokota, Y. Kakuchi, and Y. Takada, Polym. J., 8, 495 (1976).

3. T. Kakuchi, K. Yokota, and Y. Takada, Reports of the Asahi Glass Foundation for Industrial Technology, 37, 49 (1980).

4. T. Otsu and Y. Horiomoto, Mem. Fac. Eng., Osaka City Univ., 18, 99 (1977).

5. K. Yokota, N. Kaneko, J. Iwata, K. Komuro, and Y. Takada, Polym. J., 11, 929 (1979).

6. K. Yamaguchi,K. Yokota, and Y. Takada, Makromol. Chem., 182, 669 (1981).

7. K. Yamaguchi, K. Yokota, and Y. Takada, Makromol. Chem., submitted.

8. T. Holt and W. Simpson, Proc. R. Soc. London, Ser. A, 238, 154 (1956).

9. C. S. Marvel and W. E. Garrison, Jr., J. Am. Chem. Soc., 81, 4737 (1959).

10. S.-C. Chu and G. B. Butler, J. Polym. Sci., Polym. Lett. Ed., 15, 277 (1977).

11. R. Asami and J. Kondo, Polym. Prepr., Jpn., 26, 98 (1977); 27, 571 (1978).

12. A. Matsumoto, K. Aoki, Y. Kukimoto, and M. Oiwa, Polym. Prepr., Jpn., 30, 22 (1981).

13. C. Galli, G. Illuminati, L. Mandolini, and P. Tamborra, J. Am. Chem. Soc., 99, 2591 (1977).

14. G. Illuminati, L. Mandolini, and B. Masci, J. Am. Chem. Soc., 99, 6308 (1977).

15.. L. Mandolini, J. Am. Chem. Soc., 100, 550 (1978).

16. J. Roovers and G. Smets, Makromol. Chem., 60, 89 (1963).

17. K. Yokota, T. Kakuchi, and Y. Takada, Polym. J., 10, 19 (1978). 